\title{
Uma nota sobre os diferentes conceitos de taxa de juros de equilíbrio e os dilemas da política econômica no Brasil
}

José Luís Oreiro*

O objetivo da presente nota é esclarecer questões de natureza teórica que, em nossa opinião, são extremamente relevantes para que se possa compreender o papel do regime macroeconômico no processo de semi-estagnação o qual a economia brasileira vivencia desde a adoção do câmbio flutuante e do sistema de metas de inflação em 1999.

O ponto de nossa argumentação pode ser compreendido com a ajuda da Figura 1 abaixo. No eixo horizontal, estamos representando o produto real $(\mathrm{Y})$, ao passo que a taxa de juros real (r) está sendo representada no eixo vertical. A Curva IS, com inclinação negativa, representa o locus das combinações entre taxa de juros e produto reais para as quais a demanda planejada de bens e serviços (igual à soma entre consumo, investimento, gastos do governo e exportações líquidas) é igual ao nível de produção programada pelas firmas de tal forma que o mercado de bens se encontra em equilíbrio. A posição da curva IS no plano taxa real de jurosproduto depende do nível de gastos do governo em termos reais $(G)$, do componente autônomo dos gastos privados de investimento $\left(\mathrm{I}_{0}\right)$, da taxa real de câmbio (q) e da renda do resto do mundo $\left(\mathrm{Y}^{\mathrm{RM}}\right)$. A reta vertical $\mathrm{Y}^{*}$ representa o produto potencial, ou seja, o volume de produção de bens e serviços que pode ser produzido, num dado ponto do tempo, se os fatores de produção (capital e trabalho) estiverem sendo plenamente empregados.

\footnotetext{
* Doutor em Economia pelo Instituto de Economia da UFRJ. Professor do Departamento de Economia da UFPR. Pesquisador do CNPq e Coordenador do boletim de conjuntura Economia \& Tecnologia. Endereço eletrônico: joreiro@ufpr.br Página Pessoal: www.joseluisoreiro.ecn.br.
} 


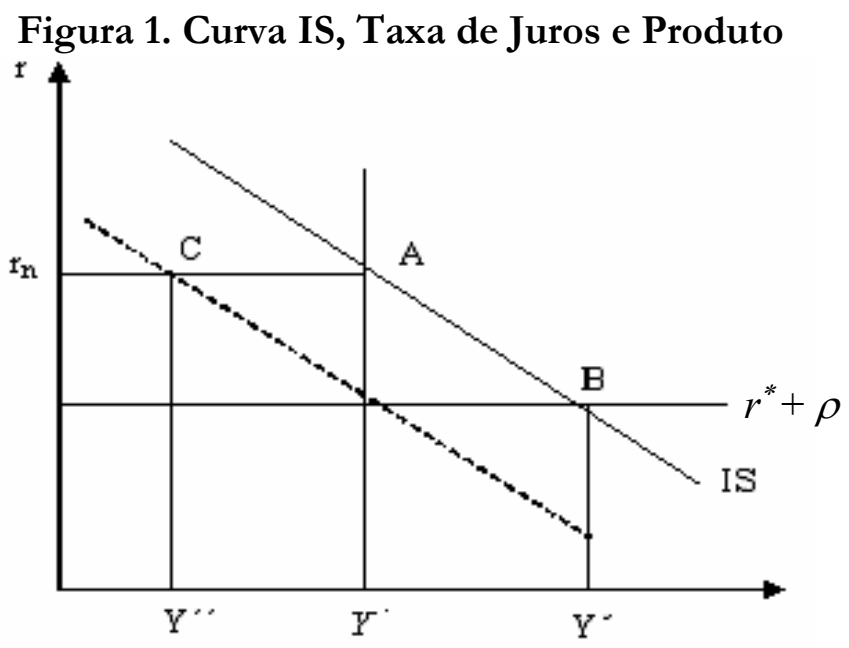

Fonte: elaborado pelo autor.

Iremos supor uma pequena economia aberta com câmbio flutuante, mobilidade de capitais e metas de inflação. Nesse contexto, consideremos que o Banco Central persegue uma meta de inflação constante. Para que a inflação permaneça constante ao longo do tempo, a economia deve operar com um nível de produção igual ao potencial. Se o nível de produto real $\left(\mathrm{Y}^{\prime}\right)$ para o qual o mercado de bens está em equilíbrio for maior do que o nível do produto potencial $\left(\mathrm{Y}^{*}\right)$, tal como ocorre no ponto $\mathrm{B}$, então surgirão pressões inflacionárias na economia que farão com que a inflação se acelere ao longo do tempo. Para impedir que isso ocorra, o Banco Central deve aumentar paulatinamente a taxa de juros nominal e real até o ponto A da figura 1. Neste ponto, o produto real será igual ao produto potencial e a inflação permanecerá constante ao longo do tempo.

A taxa real de juros determinada no ponto A da figura 1 é denominada de taxa natural de juros, ou seja, o valor da taxa de juros real para o qual a inflação permanece constante ao longo do tempo (cf. Wicksell, 1997). Com essa taxa de juros, a economia está operando com um nível de produto igual ao potencial, logo, segue-se que a taxa natural de juros assegura o equilíbrio interno da economia em consideração.

Contudo, numa pequena economia aberta com mobilidade de capitais, o valor da taxa de juros real que assegura o equilíbrio externo (saldo do balanço de pagamentos igual a zero) só por uma feliz coincidência será igual à taxa natural de juros. De fato, a taxa real de juros de equilíbrio externo é igual à soma entre a taxa real de juros internacional $\left(\mathrm{r}^{*}\right)$ e o prêmio de risco-país $(\rho)$, ambos independentes das variáveis que determinam a posição da curva IS, assim como o nível do produto potencial. 
$\mathrm{Na}$ figura 1 estamos supondo que o valor da taxa real de juros que assegura o equilíbrio externo é menor do que o valor da taxa real de juros que assegura o equilíbrio interno. $\mathrm{O}$ diferencial existente entre a taxa de juros que assegura o equilíbrio interno $\left(r_{n}\right)$ e a taxa de juros que garante o equilíbrio externo $\left(\mathrm{r}^{*}+\rho\right)$ abre um espaço enorme para a realização de ganhos de arbitragem entre títulos domésticos e internacional. Dessa forma, haverá uma entrada considerável de capitais de curto prazo, produzindo assim uma apreciação da taxa nominal e real de câmbio.

A situação apresentada na figura 1 parece ser a situação prevalecente na economia brasileira (Oreiro, 2006). Com efeito, tal como mencionamos em ocasiões anteriores, existem boas razões para acreditarmos que a taxa de juros real que proporciona o equilíbrio externo da economia brasileira se situa entre $6 \%$ e $6,5 \%$ ao ano. Por outro lado, as estimativas existentes sobre a taxa natural de juros da economia brasileira apontam para um valor entre $10 \%$ e $11 \%$ ao ano. Nesse contexto, as autoridades monetárias se encontram diante de um dilema: se reduzirem a taxa de juros real para o patamar compatível com o equilíbrio externo, então haverá uma aceleração da inflação, pondo em cheque o regime de metas inflacionárias e a própria estabilidade de preços, duramente conquistada ao longo dos últimos 12 anos. Mas se mantiverem a taxa real de juros no nível da taxa natural de juros, então o processo de apreciação da taxa real de câmbio irá continuar, pondo em risco a solvência externa da economia brasileira no longo prazo.

A solução que o Banco Central do Brasil tem encontrado para enfrentar esse dilema de política econômica tem sido: (i) manter a taxa real de juros em linha com as estimativas existentes da taxa natural de juros, de forma a manter a inflação sob controle; e (ii) intervir no mercado de câmbio por intermédio de operações de compra de reservas com o objetivo de impedir ou amenizar o processo de apreciação da taxa real de câmbio resultante da divergência entre a taxa de juros de equilíbrio interno e de equilíbrio externo.

Está claro que esta solução é apenas um paliativo temporário para o problema em consideração. As reservas internacionais à disposição da economia brasileira estão muito próximas de qualquer estimativa minimamente plausível a respeito do nível ótimo das mesmas. O próprio diferencial entre as duas taxas de juros de equilíbrio torna essas operações de compra de reservas extremamente dispendiosa do ponto de vista das contas do Tesouro Nacional.

A solução definitiva para o problema aqui apresentado é a mudança no mix de política econômica. É necessário que se faça uma forte contração fiscal seguida por uma 
redução rápida da taxa real de juros em direção ao patamar compatível com o equilíbrio externo da economia brasileira. A contração fiscal irá deslocar a curva IS para baixo em direção à linha tracejada na figura 1. A redução da taxa real de juros, por sua vez, irá impedir que essa contração fiscal tenha efeitos recessivos, mantendo o produto real num nível próximo ao potencial.

Se a contração fiscal não for seguida por uma rápida redução da taxa real de juros, então a economia irá operar no ponto $\mathrm{C}$ da figura 1 , com um nível de produto $\left(\mathrm{Y}^{\prime \prime}\right)$ menor que o produto potencial, de forma que a economia entrará em recessão. Daqui se segue que a solução para os problemas macroeconômicos do Brasil passa necessariamente pela coordenação entre as políticas monetária e fiscal com vistas: (i) a uma redução forte da taxa real de juros; e (ii) ao término do processo de apreciação da taxa real de câmbio. Para que essa coordenação possa ser feita, contudo, é necessário que o Banco Central do Brasil e as demais esferas de governo passem a dialogar entre si ao invés de ficarem se "digladiando" por espaços de poder, tal como tem ocorrido durante a administração do presidente Luis Inácio Lula da Silva.

\section{Referências Bibliográficas}

OREIRO, J. L. (2006). “O Comportamento Recente da Taxa Real de Juros no Brasil: existe espaço para uma queda maior da taxa de juros?”. Economia \& Tecnologia, Ano 02, Vol.06.

WICKSELL, K. (1997). "A Influência da Taxa de Juros sobre os Preços” In: Carneiro, R. (org.). Os Clássicos de Economia, Vol. 1, São Paulo: Ed. Ática. 